\title{
Approcci metodologici finalizzati alla conoscenza geometrica di torri e campanili
}

\author{
Margherita Cicala
}

\begin{abstract}
Il contributo si propone di mettere in evidenza il legame imprescindibile che esiste tra la metodologia del rilievo architettonico, espresso attraverso le sue più varie forme e tecniche di rappresentazione, e la disamina della produzione scientifica pregressa, mettendo in luce le numerose forme appartenenti al processo di conoscenza, di cui il rilievo rappresenta il momento qualificante. In tal senso sono state studiate le tecniche sino a oggi adoperate per il processo di rilevamento per una specifica categoria architettonica quali torri e campanili, strutture da sempre non adeguatamente conosciute nella propria 'individualità architettonica' e sempre annesse alla predominate costruzione della chiesa, malgrado le loro caratteristiche tipologiche e geometriche diano loro una propria peculiarità architettonica da valorizzare. Lo studio intende, mettere in relazione i linguaggi di rilievo e rappresentazione adoperati dall'antichità e basati sui principi della geometria euclidea fino all'applicazione delle nuove strumentazioni digitali che dona al disegno una nuova forma espressiva di linguaggi, rispettivamente per la documentazione e la gestione delle innanzi citate architetture. II caso studio applicativo inerente l'analisi del centro storico del comune di Riardo (CE) consentirà di cogliere il valore comunicativo delle nuove tecnologie digitali che malgrado si discostino per prassi metodologica dal linguaggio di rilievo antico e consolidato nel tempo conserva con esso una significativa relazione teorica.
\end{abstract}

Parole chiave

rilievo architettonico, architetture snelle, metodologie, trattatistica, drone.

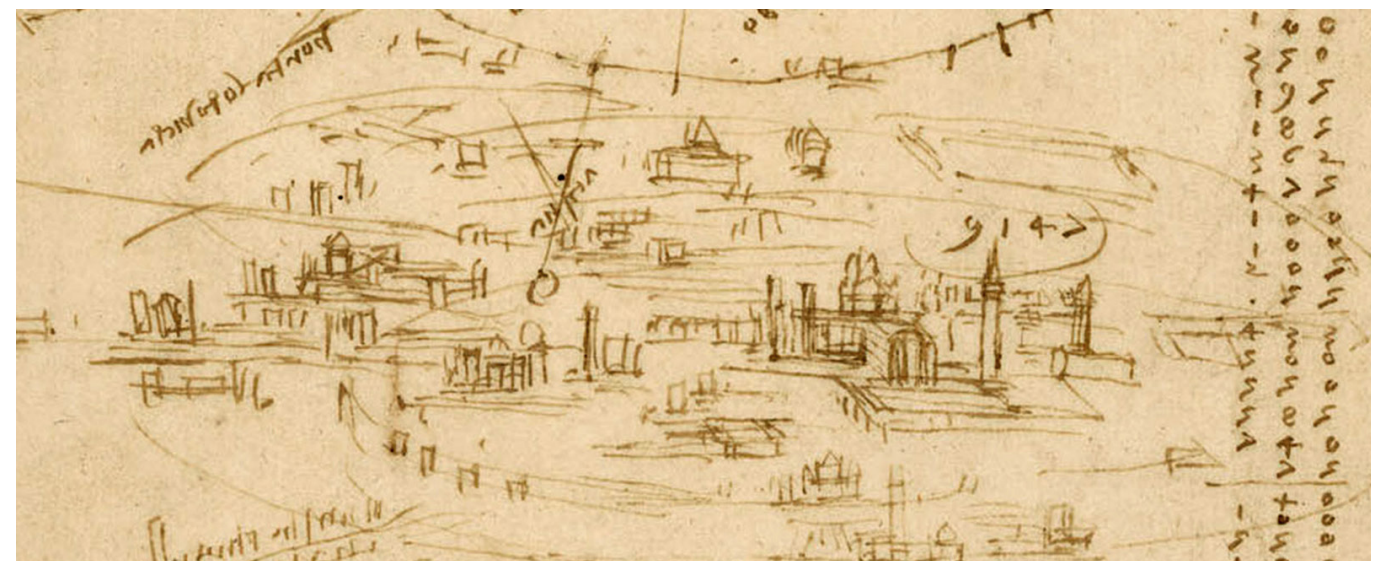




\section{Introduzione}

Oggetto della seguente indagine di ricerca è lo studio delle strutture architettoniche a caratterizzazione 'verticale' o 'snelle', mediante un processo metodologico di rilievo e di rappresentazione [I]. II tema risulta essere una valida occasione per sperimentare e valutare le potenzialità di quelle che sono le consuete tecniche tradizionali di rilievo geometrico, relazionate alle nuove metodologie di rilievo digitale integrato. Difatti, lo studio di questa tipologia architettonica si inserisce in modo confacente nell'area del Rilievo Architettonico che da sempre ha indotto l'uomo a sperimentare sempre più adeguate tecniche di rilievo per poter 'misurare' tali strutture 'inaccessibili'. Tale motivo le ha rese nel tempo come elemento di riferimento per i maggiori eruditi del tempo che le hanno 'adoperate' da riferimento architettonico per le sperimentazioni del rilievo indiretto e la determinazione di quelle 'distanze' qui intese come 'misura metrica'. Lo studio si articola in due sezioni. Una prima parte, volta ad approfondire la tematica delle metodologie applicative del rilievo architettonico di queste segnalate strutture snelle adoperate in antichità, improntato sulla disamina della produzione scientifica pregressa, dunque delle tecniche di misurazione e delle strumentazioni di misura, i cui protagonisti sono stati i teorici e trattatisti. La seconda parte di indagine è volta ad analizzare l'evoluzione delle tecnologie di rilievo che sono giunte alla determinazione di quelle nuove tecniche di rilievo che adoperano moderne strumentazioni, in grado di annullare sia le distanze spaziali ma soprattutto quelle temporali rispetto agli assunti del passato. In tale fase sarà analizzato il centro storico del comune di Riardo (CE) individuando i campi di applicazione e la strumentazione adottata, per un confronto tra le metodologie tradizionali rispetto a quelle innovative. Dunque, quest'ultima parte applicativa di indagine è volta all'analisi del procedimento da adottare per una restituzione in bi-tridimensionale dei campanili, che consenta una loro successiva valorizzazione.

\section{Le tecniche di rilievo metrico antico delle architetture 'snelle'}

In questa fase di analisi si è proceduto a una disamina dettagliata della produzione scientifica pregressa inerente la prassi di rilevamento delle strutture architettoniche 'snelle'.

Dunque, il primo segmento per la metodologia di ricerca è stata l'investigazione dello stato dell'arte, in modo tale da valutare come è evoluta nel tempo la prassi di rilievo geometrico delle torri e quali siano state le tecniche di rilevamento adoperate in antichità, soprattutto

Fig. I. Talete, schema geometrico inerente la misurazione dellaltezza di una piramide mediant il principio delle

ombre, visualizzazion

in bidimensionale

e tridimensionale

(elaborazione grafica M. Cicala).

Fig. 2. Schema geometrico della misurazione dell'altezza di un generico campanile secondo il principio diTo Prista tridimensionale vista trimensiona (elaborazione grafica M. Cicala).
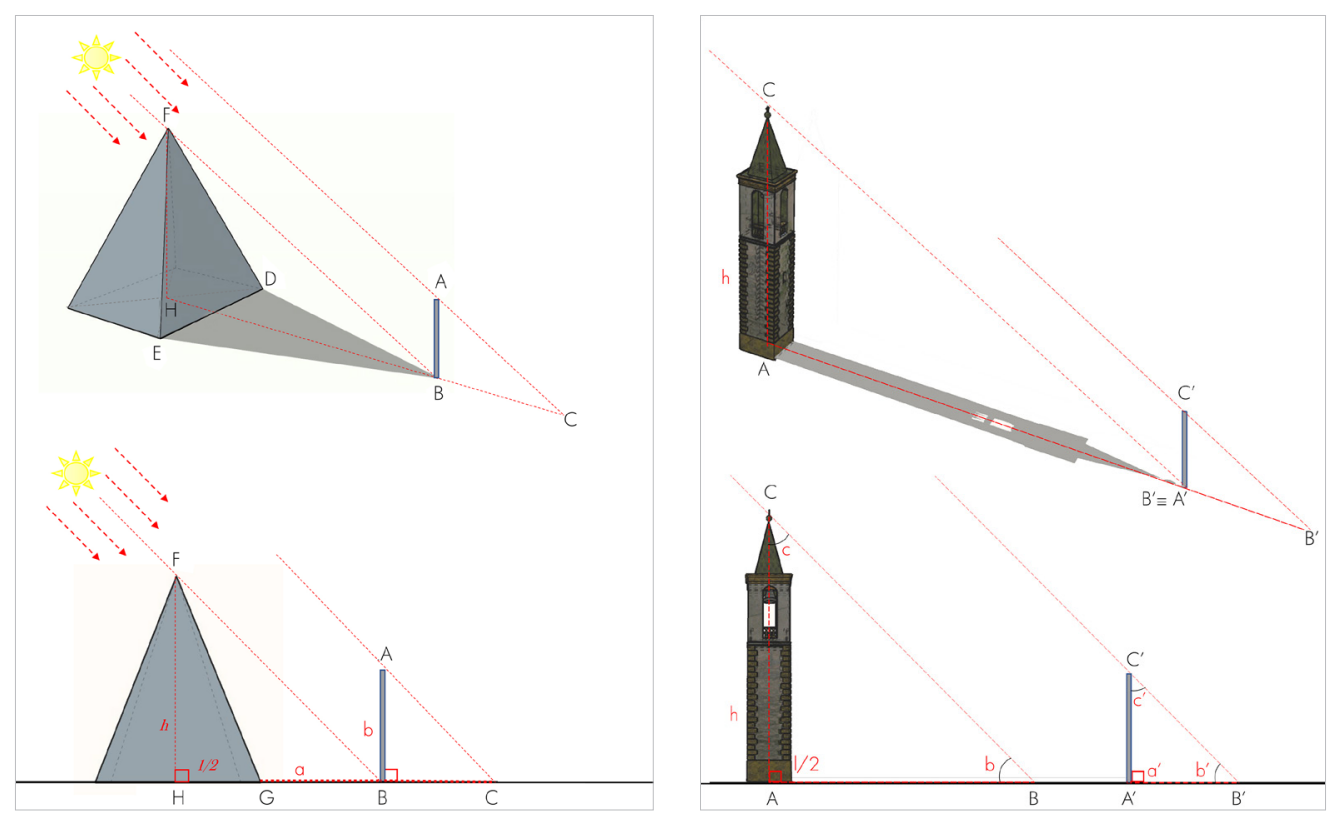
Fig. 3. Villard de Honnecourt, Taccuino Livre de portraiture. Misurazione dell'altezza di una torre mediante il metodo dei triangoli simil. Parigi, BN, fr. 19093.
Fig. 4. Strumenti di misurazione utilizzati in antichità: a sinistra una tavola di sintesi estratta da trattato di G. Pomodoro inerente gli strumenti adoperati per il rilievo adoperati per il rilievo destra una squadra mobicestra una squadra mobi- Fabri un hom . Fabrie un holometro estratto dal trattato di A Foullon.

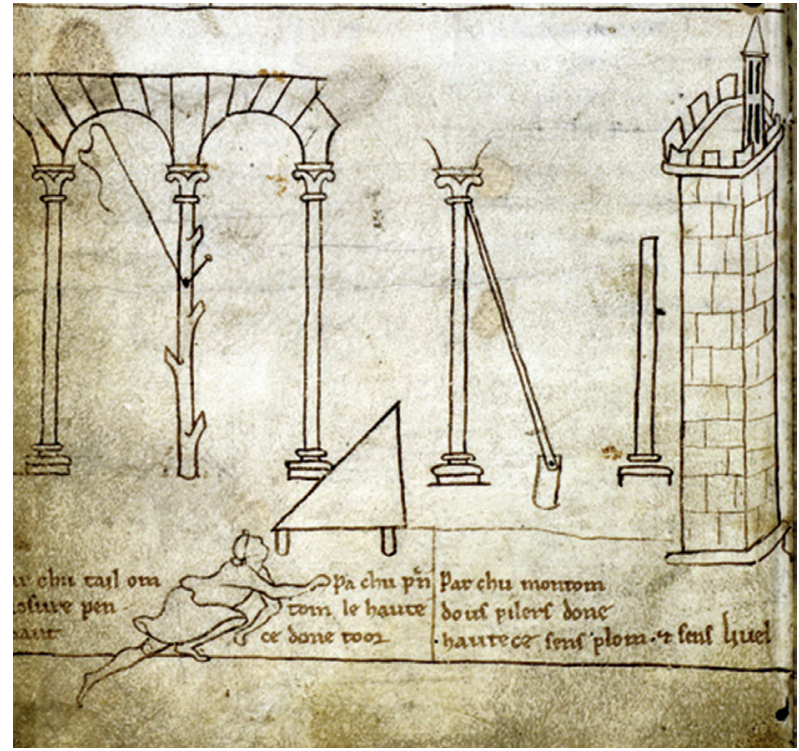

per la determinazione delle altezze. Relativamente alla pubblicistica esaminata bisogna osservare che la letteratura critica risulta essere particolarmente scarna. Non si intendono i saggi cui si fa riferimento, ma studi di ampio respiro che analizzino l'argomento in modo approfondito e, soprattutto, comparato. Essa si divide in due grandi filoni, il primo che adopera i consueti metodi tradizionali di rilevamento, e in contrapposizione, una prassi di rilievo eseguita mediante i nuovi strumenti tecnologici.

II rilievo architettonico delle strutture snelle è strettamente correlato alla prassi di rilevamento topografico in cui confluiscono più discipline: disegno geometrico, matematica, agrimensura, ingegneria militare. II passaggio dall'analisi teorica all'effettiva pratica del rilievo di dette strutture ottiene un massimo sviluppo nel Cinquecento, con l'ideazione e l'utilizzazione di un gran numero di strumenti, il cui utilizzo ha consentito di giungere alla riproduzione di uno spazio misurato, dunque di raggiungere l'obiettivo ultimo della prassi del rilevamento, così come definito dai trattati di ingegneria militare [Zerlenga 1993]. In tal senso, sono state analizzate le tecniche di rilevamento indirette tradizionali, che fondano il proprio utilizzo sul ricorso alla conoscenza scientifica in termini di trigonometria. II primo riscontro per la misurazione di un'altezza con metodo indiretto lo si ha con il matematico Talete di Mileto (640 a.C./625 a.C.c. - 548 a.C./545 a.C.ca.), che misurò l'altezza delle piramidi egizie avvalendosi dei principi geometrici che sfruttano la misurazione delle ombre generate dalle stesse (figg. I, 2) [Klimpert I90 I]. A partire dall'XI sec., la misurazione altimetrica delle torri usufruisce

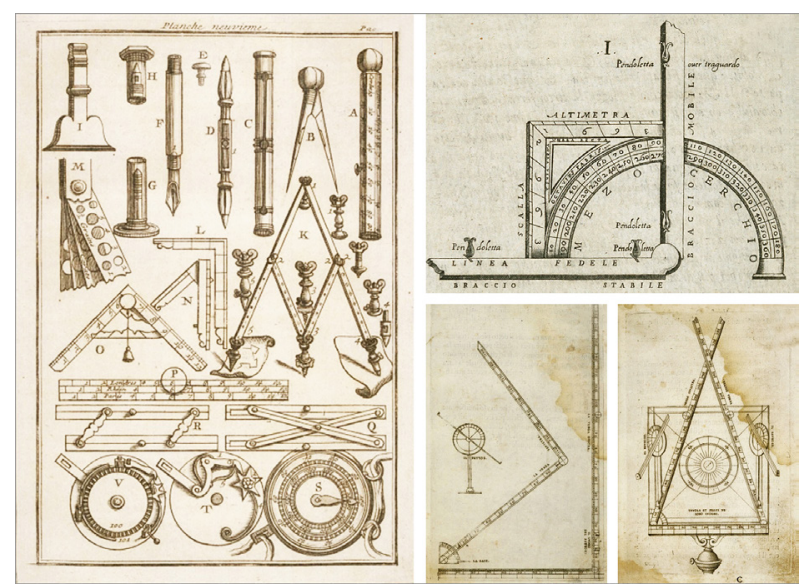


di tecniche che, sono dedotte dall'applicazione dei rigorosi progressi teorico-scientifici nelle discipline geometriche: gli Elementi di Euclide, l'Almagesto di Tolomeo o le opere sulla trigonometria di Teodosio e Fibonacci. Le prime tecniche specifiche sugli accorgimenti da adottare per determinare l'altezza di una torre sono descritte nel taccuino Livre de portraiture (I230-36 ca.) [Lassusa, Darcel I858] di Villard De Honnecourt in cui è indicato il ricorso geometrico al sistema dei triangoli simili (fig. 3). Singolare è il trattato di Geraldo di Aurillac poi papa Silvestro II (940-950 ca. - I003) [Hock 20 I0], in cui è illustrata per la prima volta una metodologia scientifica che fonda le proprie radici negli assunti geometrici di derivazione araba, costruendo il procedimento sulla figura geometrica del triangolo rettangolo, la cui prassi fungerà da cardine pratico e teorico a partire dal sec. XV. Altra illustre figura è Leonardo Pisano conosciuto da molti come Fibonacci ( I I70 ca. - I242 ca.) ove nella sua opera Pratica geometriae ( 1223 ) esamina la misurazione delle altezze con l'uso di una semplice pertica anticipando gli assunti illustrati in seguito dall'Alberti.

Sarà dunque a partire dal XV sec. che con l'intensificarsi del rapporto tra la scienza e la tecnica si assisterà alla pubblicazione dei trattati da parte di artisti, architetti, ingegneri militari [Docci, Maestri 1984], per mezzo dei quali si innesta una forte relazione fra la misurazione topografica del territorio e quella dell'architettura, divulgandosi così pratiche più concrete che sfruttano l'uso di strumentazioni scientifiche consone al rilevamento geometrico. I rilevatori, i topografi, gli agrimensori-cartografi in antichità adoperavano logiche di tracciamento basate sulla raccolta dati di punti trigonometrici che, spesso, corrispondevano a elementi architettonici connotati da un'altezza significativa e, pertanto, coincidenti con emergenze visive in virtù delle quali era possibile ottenere i dati per la misurazione delle distanze nonché delle altezze nello spazio. La disamina della trattatistica scientifica dimostra che queste architetture non fungevano solo da 'marcatori' visivi ma anche da architetture 'adeguate' a sperimentare nuove tecniche di misurazione. Nel testo sul Modo di misurare il circuito o ambito di una terra ( | 450-52) di Leon Battista Alberti ( | 404- |472) è illustrato l'uso del dardo per misurare l'altezza di una torre con l'applicazione della teoria dei triangoli simili, della similitudine dei triangoli rettangoli e del teorema di Talete.

Tra la fine del sec. XV e l'inizio del sec. XVI in Italia furono molti i trattatisti che si avvalsero di queste architetture per illustrare le metodiche di impiego dei diversi dispositivi di misurazione che sarebbero confluiti nelle rispettive pratiche di rilevamento topografico-militare: squadra mobile, il quadrante geometrico, il radio latino, l'olometro, oltre che i comuni dardi, fili a piombo o aste metriche (fig. 4). Citando solo alcuni fra i trattati più significativi, nel trattato Del modo di misurare le distanze [... ] del I 564 di Cosimo Bartoli (I503-I 572) egli sviluppa una singolare sintesi di tutte le tecniche sino ad allora utilizzate dai suoi predecessori, attraverso molteplici casistiche che richiamano i postulati euclidei (figg. 5, 6, 7); nel trattato Descrittione et uso dell'Holometro [...] del 1564 di Abel Fullone (I5|3-I563) è illustrata la misurazione di una torre con l'ausilio del suddetto strumento sfruttando il

Fig. 5. Bartoli C., Del modo di misurare le distantie [...], I564. Misurazione di una distanza in piano con il quadrante geometrico
(elaborazione grafica $\mathrm{M}$. Cicala).

Fig. 6. Bartoli C., Del modo di misurare le distantie [...], I 564. Misurazione di una linea in piano partendo dall'altezza di una torre (elaborazione grafica M. Cicala).
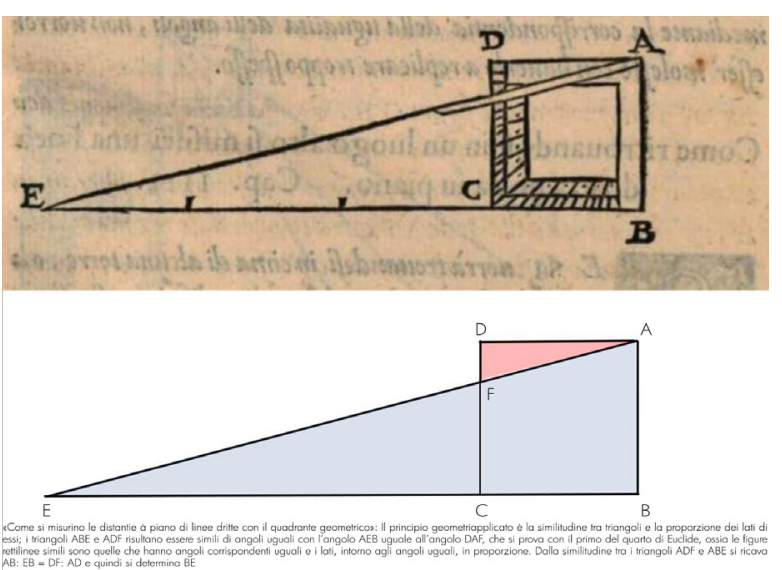

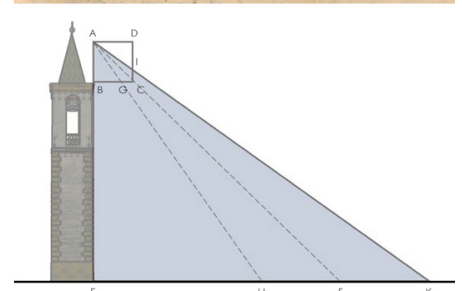


principio della similitudine fra triangoli; nel trattato Radio Latino Istrumento giustissimo \& [...] del I583, Egnazio Danti (I536- |586) mostra le regole di "come si misuri da una valle l'altezza d'una torre" (fig. 8) [Danti I583] con l'uso del radio latino; nel I598 Ottavio Fabri ( I545- | 6 I I ca.) definisce l'utilizzo della squadra zoppa per rilevare i campanili (fig. 9) [Fabri 1598]. Questa breve panoramica dimostra che a partire dalla seconda metà del sec. XVI le tecniche e gli strumenti di misurazione arriveranno a un'elevata esattezza. Al contempo, queste acquisizioni tecnico-scientifiche dimostrano quanto da queste prassi derivino i criteri di rilevamento e disegno architettonico contemporaneo indiretto, eseguito con innovativi strumenti tecnologici che per l'appunto accorciano le 'distanze' tra il passato e il presente.

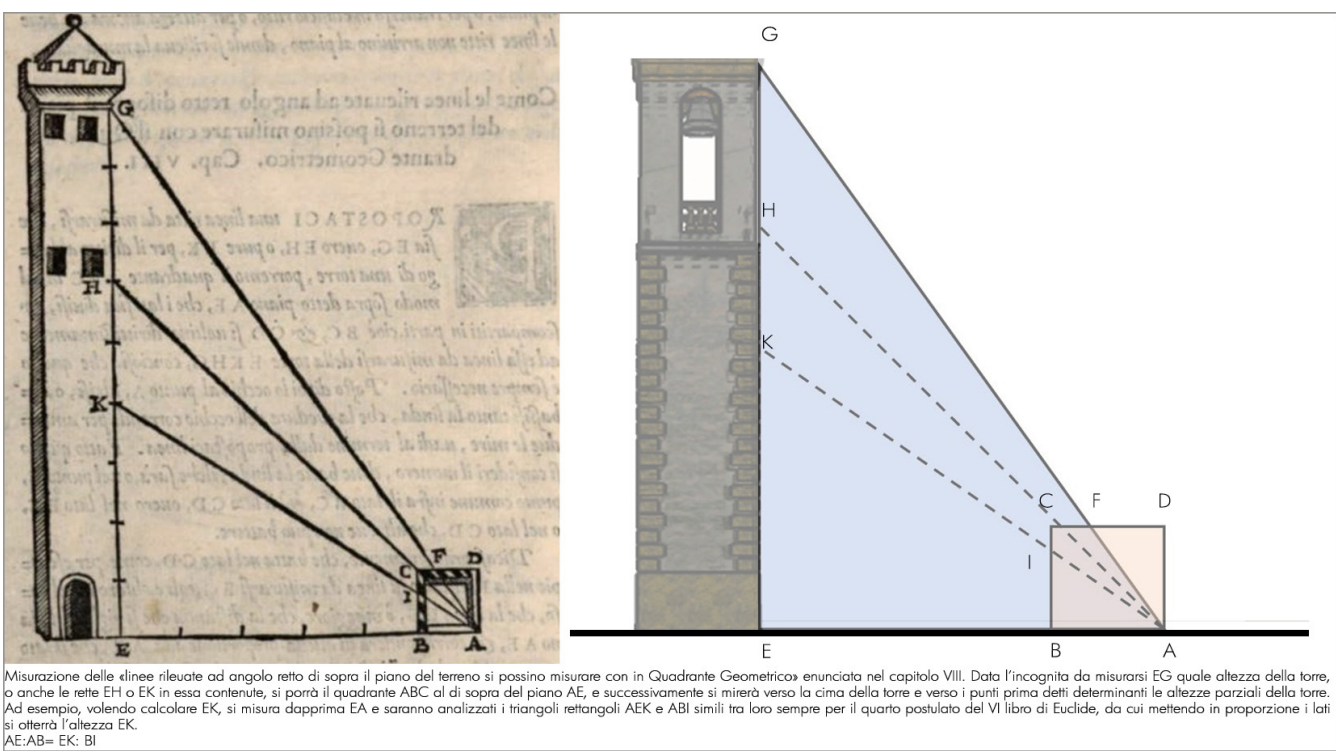

\section{Le nuove tecnologie per il rilievo}

Oggigiorno per rilevare un campanile, è possibile procedere mediante un rilievo tramite il metodo diretto con un rilevamento longimetrico supportato dall'ausilio di semplici strumenti di misura, quali il metro, aste metriche, il filo a piombo per verificare la direzione verticale e quindi individuare le misure altimetriche; l'uso delle consuete tecniche di rilevamento: delle ascisse e delle ordinate, delle misure parziali e progressive o della trilaterazione. Ma nella circostanza in cui sia impossibile svolgere un rilievo diretto del manufatto, come dimostrato per quasi tutta la casistica esaminata, a supporto del metodo diretto è inevitabile la necessità di integrare ai dati ottenuti quelli ricavati grazie al sussidio di strumentazione indiretta 'moderna': stazioni totali, tacheometri, livelli, distanziometri, laser scanner, APR, soprattutto per rilevare punti inaccessibili. Nello specifico, per quanto concerne la metodologia del rilievo indiretto moderno notevolmente adoperata per il rilievo di architetture verticali è quella topografica, per mezzo della quale è possibile definire l'oggetto attraverso la misura di angoli, mentre la misura delle distanze è ridotta al minimo, consentendo la lettura a distanza delle misure relative ad angoli e lunghezze mediante i principi della trigonometria.Tra i vari esempi applicativi di questa prima metodologia i più significati rinvenuti sono il rilievo geometrico del Torrazzo di Cremona (CR) [Cuzzoni 202 I], il campanile di Pietrasanta (LU) [Russo 20 I4] o ancora il campanile di Gaeta (LT) [Pedone, Paribeni 20 I4], esempi che testimoniano come tale metodologia per quanto classicista tradizionale, che trae le sue origini nell'architettura greca e romana, se effettuata a norma, consente di ottenere dei risultati che siano in grado di rispecchiare idoneamente la realtà oggettiva del bene analizzato, con un livello di incertezza quanto più basso [Zerlenga 2000]. 
Fig. 8. Danti E., Trattato de Radio Latino. Instrumento [...], I583. Misurazione dell'altezza di un bastione tramite l'uso del radio atino (elaborazione grafica M. Cicala).

Fig. 9. Fabri O., L'uso della Squadra Mobile [...], I589. Definizione di quattro casistiche per determinazione delle altezze (elaborazione grafica M. Cicala).
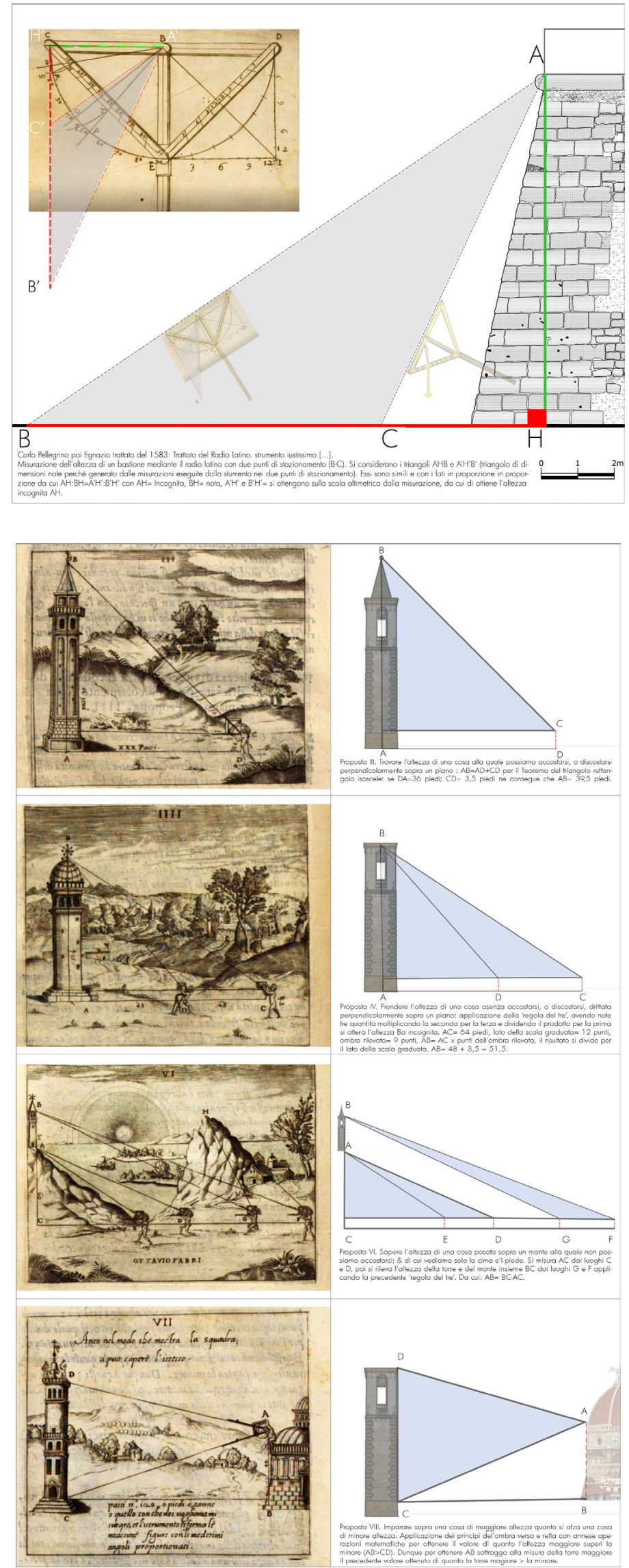
Con il trascorrere del tempo le tecniche per l'esecuzione del rilievo e la sua rappresentazione si sono sempre più affinate, attraverso la produzione di macchinari e strumenti digitali, capaci di garantire una maggiore precisione metrica che induce a ridurre lo scarto di errore e il tempo impiegato per la raccolta dati. Tra questi abbiamo la metodologia della fotogrammetria digitale che offre un approccio di metodo semplice ed economico al fine di rilevare metricamente il patrimonio culturale. Adoperata per l'analisi delle rovine del campanile della Confraternita della Misericordia a Savigliano [Lingua, Piumattli 20 I2], o ancora per il Duomo e il Campanile di Cremona [Balletti, Pilot 1998], questo procedimento, è costituito da software innovativi capaci di gestire tutte le prassi fotogrammetriche. I documenti citati descrivono un'organizzazione di rilevamento metrico derivante da fotogrammi e la post costruzione dei modelli 3D, così da estrarre le rappresentazioni tradizionali necessarie per comprendere l'oggetto e pianificare una corretta procedura di analisi.

Altre due tecniche diffuse per la procedura del rilievo sono l'utilizzo degli scanner 3D e dei droni o APR. La prima metodologia consente di ottenere un'acquisizione geometrica 3D sia degli interni, che degli esterni ove accessibili, attraverso una campagna di digitalizzazione che consente di ottenere un numero definito di scansioni, le quali unite tra loro generano delle nuvole dei punti, da cui è possibile ricostruire il modello tridimensionale. L'utilizzo di APR è qui analizzato nel dettaglio mediante l'illustrazione del caso studio. II rilievo in oggetto eseguito in data 26-10-20I6 ha sfruttato I'utilizzo di drone DJI FC330 per l'acquisizione dei dati geometrici dei manufatti che non erano raggiungibili in modo diretto, come le coperture nel loro sviluppo plano-altimetrico e soprattutto per la torre dell'orologio (fig. I 0). La tecnica adoperata ha consentito dagli scatti eseguiti di generare una nuvola di punti densa tramite il software PhotoscanPro (figg. II, I2), dunque in cui a ogni punto sono associate

Fig. 10. Modello della nuvola di punti estratta con il programma PhotoscanPro dell'area urbana di Riardo (CE).

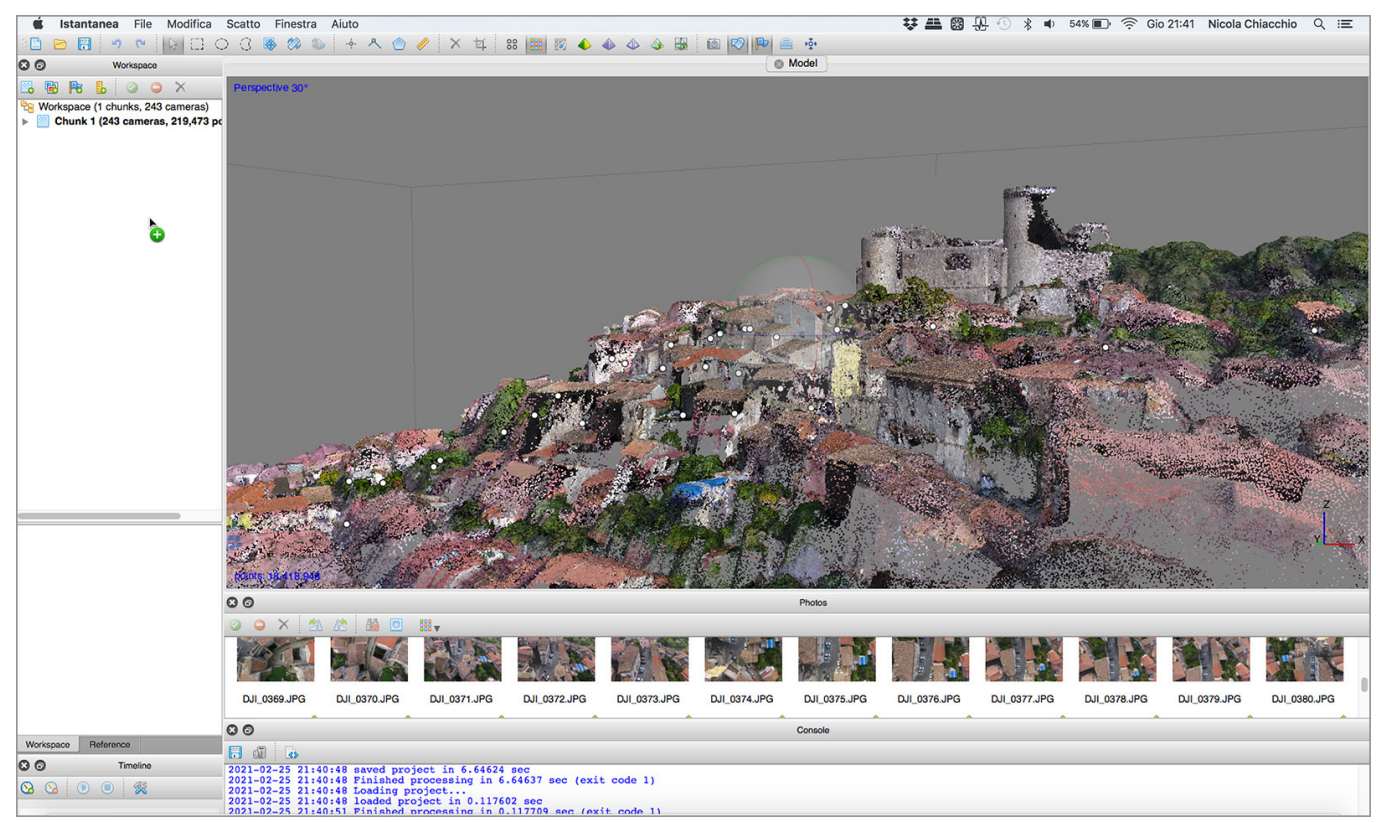

informazioni di posizione - x, y, z - e di colore - RGB - pertanto, riuscendo a originare una sagoma del reale del manufatto a partire da una sequenza di immagini, ottenendo coordinate tridimensionali da coordinate bidimensionali. Tale prassi supportata dall'uso degli APR consente di svolgere anche rilievi urbani oltre che di singoli manufatti in tempi ridotti e di produrre un modello contenente un notevole numero di informazioni geometriche e dimensionali, sulle caratteristiche cromatiche, materiche e sullo stato di rovina degli elementi architettonici. Non si vuole qui approfondire l'esplicazione del processo di acquisizione dei dati bensì rimarcare quanto essa funge da tecnica digitale innovativa cui ne consegue una 
Fig. II. Modello tridimensionale ricavato dalla fusione dei punti georeferenziati generati dal rilievo con drone.

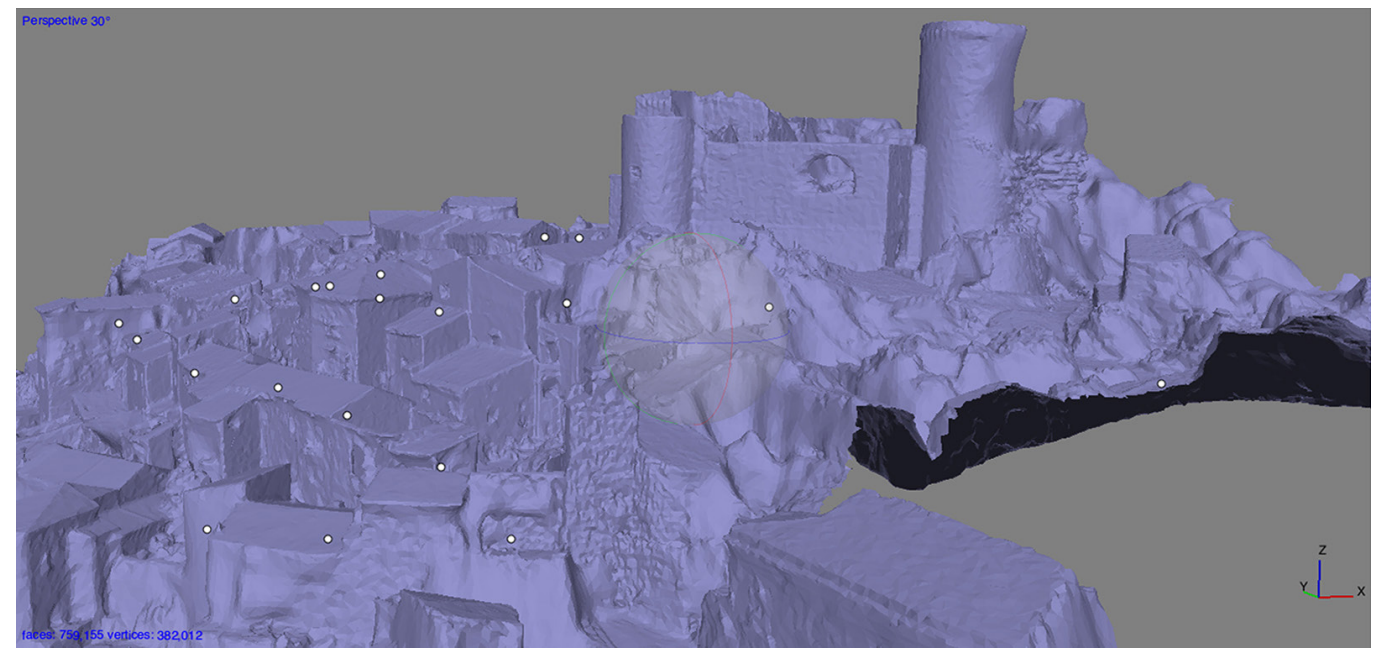

nuova rappresentazione tridimensionale in grado di sopperire ai limiti degli approcci del rilievo diretto, raggiungendo modelli completi dai quali estrapolare un notevole numero di informazioni. Ma evidenziando che tale processo 'moderno' supportato dalla tecnologia sviluppatasi nell'ultimo ventennio e in continua evoluzione discende dai principi della geometria descrittiva e dai metodi di rilievo indiretto adottati in antichità.

\section{Conclusioni}

L'obiettivo del paper è di rimarcare il legame inscindibile che vige tra i linguaggi adoperati in passato e quelli contemporanei e moderni per il rilevamento architettonico: da un lato i metodi di rilevamento antico che malgrado siano soggetti a un maggiore grado di incertezza - a causa della strumentazione non ben calibrata come quella di cui si dispone oggi - adottano le prassi della geometria euclidea come cardine procedurale per un adeguato metodo scientifico ben consolidato, in grado di abbattere le distanze nel corso del tempo e che si proietta all'interno delle nuove forme espressive digitali delle nuove tecnologie. Le nuove tecnologie impiegate per il rilievo, che appaiono sempre più tecnologicamente perfette mostrano in sé il progresso rispetto alle tecniche del passato ma il cui uso va però accuratamente filtrato, evitando di rischiare di produrre un'elaborazione e rappresentazione dei dati incapace di comunicare i caratteri singolari dell'architettura esaminata e rispettando i principi comunicativi del disegno e della sua rappresentazione con una capacità espressiva universale.

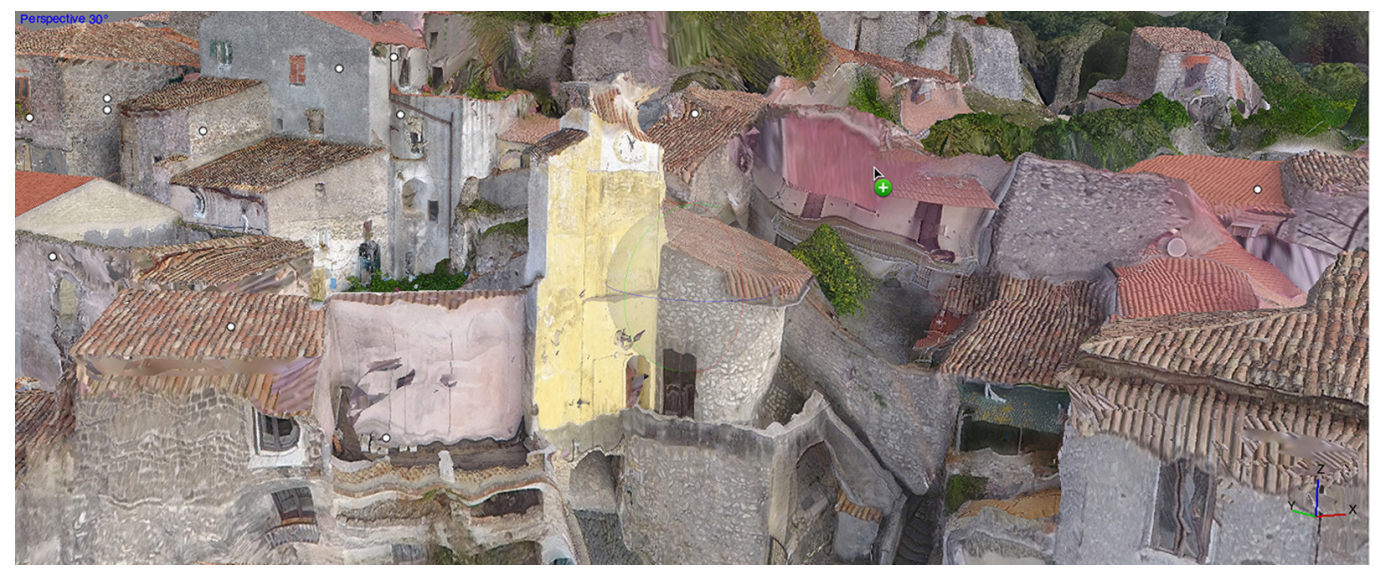

Fig. 12. Particolare della nuvola di punti inerente Riardo (CE). 


\section{Note}

[I] Tra queste architetture snelle, nello specifico i campanili in muratura di Napoli sono stati analizzati e continui studi sono in progress, nell'ambito ambito di ricerca condotta in team, all'interno del progetto competitivo intra/Ateneo PREVENT Integrated PRocedure for assEssing and improVing the resiliENce of existing masonry bell Towers at territorial scale, finanziato con Programma Valere 2019 dall'Università degli Studi della Campania "Luigi Vanvitelli" e coordinato da Gianfranco De Matteis (principal investigator) con Sergio Sibilio e Ornella Zerlenga (team leaders).

\section{Ringraziamenti}

Si ringrazia l'architetto Nicola Chiacchio per la collaborazione all'esecuzione del rilievo con drone e all'annessa elaborazione dei dati informatizzati.

\section{Riferimenti bibliografici}

Aita D. et al. (2017). 3-Dimensional geometric survey and structural modelling of the dome of pisa cathedral. The International Archives of the Photogrammetry, Remote Sensing and Spatial Information Sciences, pp. 39-46.

Alberti L. B., Bartoli C. (1568). Opuscoli morali di Leon Battista Alberti gentil'huomo firentino: né quali si contengono molti ammaestramenti, necessarij al viuer de' l'huomo, così posto in dignità, come priuato. Tradotti, \& parte corretti da Cosimo Bartoli. Venezia: Franceschini editore, pp. 507-512.

Balletti C., Pilot L., Brumana R. (1998). Plan, execution and rapresentation of an architectonic survey: the torrazzo of Cremona, Italy. International Archives of Photogrammetry and Remote Sensing, vol. XXXII, Part. 5. Hakodate, pp. 2I 0-20I 5.

Bartoli C. (I564). Del modo di misurare le distantie, le superficie, i corpi, le piante, le prouincie, le prospettiue, \& tutte le altre cose terrene, che possono occorrere a gli huomini, secondo le vere regole d'Euclide, \& de gli altri piu lodati scrittori. Venetia: per Francesco Franceschi Sanese.

Cirillo V., Cicala M. (2020).Valorizzare l'architettura religiosa attraverso l'arte di strada. Il campanile della chiesa di Maria Santissima del Carmine alle Fontanelle nel progetto PREVENT. In A. di Luggo, O. Zerlenga (a cura di). Street Art. Drawing on the Walls. Napoli: La scuola di Pitagora. pp. 95-121.

Cirillo V., Cicala M. (202I). Redrawing the future of Naples' bell towers. the 'prevent' project. In Apega - XV International conference on graphic expression applied to building, Redrawing the Future. Tenerife, La Laguna, on May 27-29 2021 (in corso di pubblicazione).

Cuzzoni M. Esempio di Studio del Restauro di un Campanile <https://www.campanologia.it/contenuto/pagine/0 I-ATS/ATS-PO I/ ATS-PO I-05-Progetto-Cantiere-Campanile.htm> (consultato il 25 gennaio 202I).

Danti E. ( I 583). Trattato del Radio Latino. Istrumento giustissimo \& facile più d'ogn'altro per prendere qual si voglia misura, \& positione di luogo tanto in Cielo, come in Terra. Il quale oltre alle operationi proprie sue fa anco tutte quelle della gram Regola di C. Tolomeo, et dell'antico Radio Astronomico. Inventato dall'Ill.mo et Eccell.mo Latino Orsini. di: Latino Orsini, I 6. sec. Egnazio Danti; Moretti, Marcantonio \& Brianza, Giacomo. Roma: Appresso Marc'Antonio Moretti, \& lacomo Brianzi.

Docci M., Maestri D. ( 1984). Il rilevamento architettonico. Storia metodi e disegno. Roma-Bari: Laterza Editori.

Docci M., Maestri D. (1993). Storia del rilevamento architettonico e urbano. Bari: Laterza Editore.

Fabri O. ( I 598). L'uso della Squadra Mobile con la quale per teoria et per pratica si misura geometricamente ogni distanza, altezza, profondità. S'impara à perticare, livellare, et pigliare in disegno le Città, Paesi et Provincie. II tutto con le sue dimostrationi intagliate in rame. Da Ottavio Fabri messa in luce.Venezia: appresso Francesco Barilleti, all'insegna del Mondo.

Foullon o Foulon, A. ( I 564). Descrittione, et vso dell'holometro. Per saper misurare tutte le cose, che si possono veder coll'occhio così in lunghezza, \& larghezza; come in altezza, \& profondità, ritrovato per Abel Fullone, valletto di camera del re di Francia, necessario a quelli che vogliono prontamente et senza fare alcuna ragione arithmetica sapere le distantie dè luoghi, misurare la terra, \& tor in disegno paesi, \& città. Venezia: appresso Giordano Ziletti, al segno della Stella.

Hock K. F., Stelzi G. (20 I0). Gerberto, o Sia Silvestro II Papa ed il Suo Secolo (I 846). Whitefish: Editore Kessinger Publishing, LLC.

Klimpert R. (190I). Storia della geometria, tradotto, con note e aggiunte dal Professore di Topografia nel R. Istituto Tecnico di Bari, Pasquale Fantasia. Bari: Gius. Laterza e Figli.

Lassus J. B. A., Darcel A. ( 1858$)$. Album de Villard de Honnecourt, Architecte du XIlle siècle: manuscrit publié en fac-similé, annoté, précédé de considérations sur la renaissance de l'art français au XIXe siècle et suivi d'un glossaire. Parigi: Impr. Imperiale.

Lingua A., Piumatti P., Rinaudo F. (2012). Digital photogrammetry:a standard approach to cultural heritage survey. In The International Archives of the Photogrammetry, Remote Sensing and Spatial Information Sciences, vol. XXXIV, Part. 5/WI2, pp. 2 I 0-2 I 5.

Lupicini A. ( 1582). Discorso sopra la fabrica, e uso delle nuove verghe astronomiche. Firenze: appresso Giorgio Marescotti.

Meschini A., Rossi D., Sicuranza F. (20/4). An integrated survey experience: San Francesco complex in Monterubbiano. In P. Giandebiaggi, C.Vernizzi (a cura di). Italian survey \& international experience. Atti del XXXVI Convegno Internazionale dei docenti della Rappresentazione, UID. Parma, 18-20 settembre 2014, pp. 943-952. Roma: Gangemi Editore.

Orsini L. (1615). Trattato del radio latino [...] il quale oltre alle operazioni proprie sue fa anco tutte quelle della Gran Regola di Tolomeo et dell'antico radio astronomico, con i commentatori di Egnazio Danti. Roma: appresso Marc'Antonio Moretti e Giacomo Brianzi.

Pedone S., Paribeni A. (2018). Di Bisanzio dirai ciò che è passato, ciò che passa e che sarà. Scritti in onore di Alessandra Guiglia. Roma: Bardi Editore.

Pomodoro G. (I 603). Geometria Prattica dichiarata da Giovanni Scala, sopra le tavole dell'Ecc. mo Mathematico Giovanni Pomodoro tratte d'Euclide e altri autori. Roma: Appresso Giovanni Martinelli. 
Russo V. (20|4). Paesaggio come architettura. Identità e conservazione del sito culturale di Crapolla. Nardini Editore.

Russo M., Manferdini A. (20 I 4). Integration of different methodologies for the high resolution survey for complex architectures. The Pomposa Abbey case study. In P. Giandebiaggi, C.Vernizzi (a cura di). Italian survey \& international experience. Atti del XXXV Convegno Internazionale dei docenti della Rappresentazione, UID. Parma, I8-20 settembre 20 I4, pp. 989-998. Roma: Gangemi Editore.

Valenti G. M., Baglioni L. (20|4). Experimential Applications of Architectural details survey using micro-drones. In P. Giandebiaggi, C.Vernizzi (a cura di). Italian survey \& international experience. Atti del XXXVI Convegno Internazionale dei docenti della Rappresentazione, UID. Parma, I8-20 settembre 20 I4, pp. I025-1030.

Vitruvio M. P. (1990). De Architettura.Volume I, Libro X.Traduzione Luciano Migotto. Pordenone: Edizione Studio Tesi.

Zerlenga O. (1993). II disegno dell'architettura fortificata nel XVI secolo. Realtà costituite e fonti iconografiche a confronto. Tesi di dottorato. Università degli Studi di Palermo.

Zerlenga O. (2000). Sulle ali di una farfalla. Esperienze di rilievo urbano e ambietale. Napoli: CUEN.

Zerlenga O. (2009a).... Misure in divenire... Measures in to become... Rilievo multidimensionale dei nuovi contesti urbani fra permanenze e contaminazioni. Napoli: La Scuola di Pitagora editrice.

Zerlenga O. (2009b). Formazione e innovazione all'Università. Indirizzo Arte e Disegno_Indirizzo Tecnologico. Foggia: Claudio Grenzi Editore.

Zerlenga O., laderosa R. (202I). PREVENT: Survey by UAV of the bell towers. In Apega - XV International conference on graphic expression applied to building- Apega 2021, Redrawing the Future. Tenerife, La Laguna, on May 27-29, 2021 (in corso di pubblicazione).

Zerlenga O. et al. (202I). Napoli rappresentata dai suoi campanili. Un caso studio: il progetto PREVENT. In A. Palomba, M. I. Pascariello (a cura di). La Citta' Palinsesto. Tracce sguardi e narrazioni sulla complessità dei complessi urbani storici. CIRICE 2020. IX Convegno internazionale. Napoli, $10-12$ giugno 2021 (in corso di pubblicazione).

Zevi B. (1948). Saper vedere l'Architettura.Torino: Einaudi Editore.

Autore

Margherita Cicala, Università della Campania “Luigi Vanvitelli”, margherita.cicala@unicampania.it

Per citare questo capitolo: Cicala Margherita (2021). Approcci metodologici finalizzati alla conoscenza geometrica di torri e campanili/Methodological approaches aimed at the geometric knowledge of towers and bell towers. In Arena A., Arena M., Mediati D., Raffa P. (a cura di). Connettere. Un disegno per annodare e tessere. Linguaggi Distanze Tecnologie. Atti del $42^{\circ}$ Convegno Internazionale dei Docenti delle Discipline della Rappresentazione/Connecting. Drawing for weaving relationship. Languages Distances Technologies. Proceedings of the $42^{\text {th }}$ International Conference of Representation Disciplines Teachers. Milano: FrancoAngeli, pp. 490-509. 


\title{
Methodological Approaches Aimed at the Geometric Knowledge of Towers and Bell Towers
}

\author{
Margherita Cicala
}

Abstract

The contribution aims to highlight the essential link that exists between the methodology of architectural relief, expressed through its various forms and techniques of representation, and the examination of previous scientific production, highlighting the numerous forms belonging to the knowledge process, of which the importance represents the qualifying moment. In this sense, the techniques used to date for the surveying process for a specific architectural category such as towers and bell towers have been studied, structures that have not always been adequately known in their own 'architectural individuality' and always attached to the predominant construction of the church, despite their typological and geometric characteristics give them their own architectural peculiarity to be valued. The study aims to connect the languages of importance and representation used by antiquity and based on the principles of Euclidean geometry until the application of new digital instrumentation that gives design a new expressive form of languages, respectively for the documentation and management of the above mentioned architectures. The application case study concerning the analysis of the historic centre of the municipality of Riardo (CE) It will allow us to grasp the communicative value of new digital technologies that, despite their differences in methodological practice, from the language of ancient importance and consolidated over time, retain with it a significant theoretical relationship.

Keywords

architectural survey, lean architecture, methodologies, treatises, drone.

Leonardo da Vinci, wiew a volo di uccello of the city of Milan. Biblioteca Atlanticus

Atlanticus
f. 199 verso, 1507-1510.

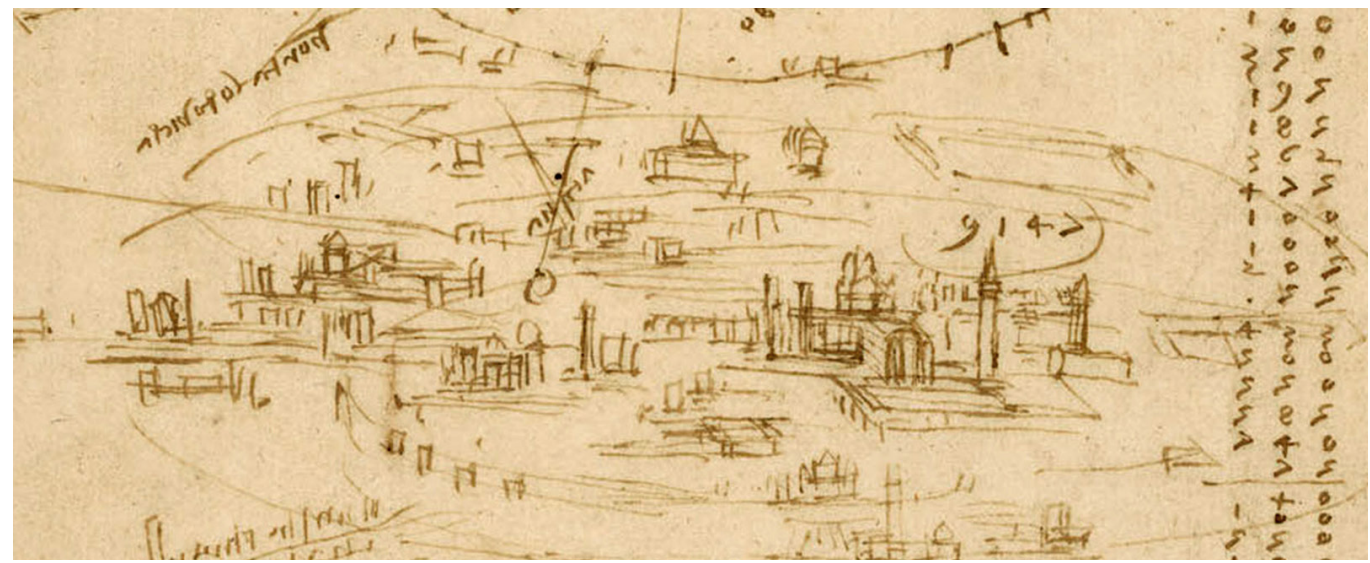




\section{Introduction}

The subject of the following research is the study of architectural structures characterized by a 'vertical' or 'lean' through a methodological process of relief and representation. The theme is a good opportunity to experiment and evaluate the potential of what are the usual traditional techniques of geometric relief, related to the new methods of integrated digital relief. In fact, the study of this architectural typology fits well into the area of Architectural Survey that has always led man to experiment more and more appropriate techniques to be able to 'measure' such 'structures' inaccessible. This reason has made them over time as a reference element for the greatest scholars of time who used them as 'architectural reference' for the experiments of indirect relief and the determination of those 'distances' here understood as 'metric measure'. The study is divided into two sections. A first part, aimed at deepening the theme of the methodologies of application of the architectural relief of these pointed lean structures used in antiquity, based on the examination of previous scientific production, therefore of measurement techniques and measuring instruments, whose protagonists were the theoreticians and treatisers. The second part of the survey aims to analyse the evolution of the relevant technologies which have arrived at the determination of those new techniques of importance which use modern instrumentation, able to cancel both the spatial distances but especially the temporal ones with respect to the assumptions of the past. In this phase the historical centre of the municipality of Riardo (CE) will be analysed, identifying the fields of application and the instrumentation adopted, for a comparison between traditional and innovative methodologies. Therefore, this last application part of the survey is aimed at analysing the procedure to be adopted for a two-three-dimensional restitution of the bell towers, allowing their subsequent valorization.

\section{The ancient metric surveying techniques of 'slender architectures'}

At this stage of analysis, a detailed examination was made of the previous scientific production concerning the practice of detecting 'lean' architectural structures [I].Therefore, the first segment for the research methodology was the investigation of the state of the art, so as to assess how the geometric survey of the towers has evolved over time and what were the detection techniques used in antiquity, especially for the determination

Fig. I.Talete, geometric scheme of measuring the height of a pyrami by the principle of shadows, two-dimensional and three-dimensional visualization (graphic elaboration by $\mathrm{M}$. Cicala).

Fig. 2. Geometric scheme of measuring the height of a generic bell tower for the principle of Talete, two-dimensiona Tand three-dimensional visualization (graphic visualization (graphic
elaboration by M. Cicala).
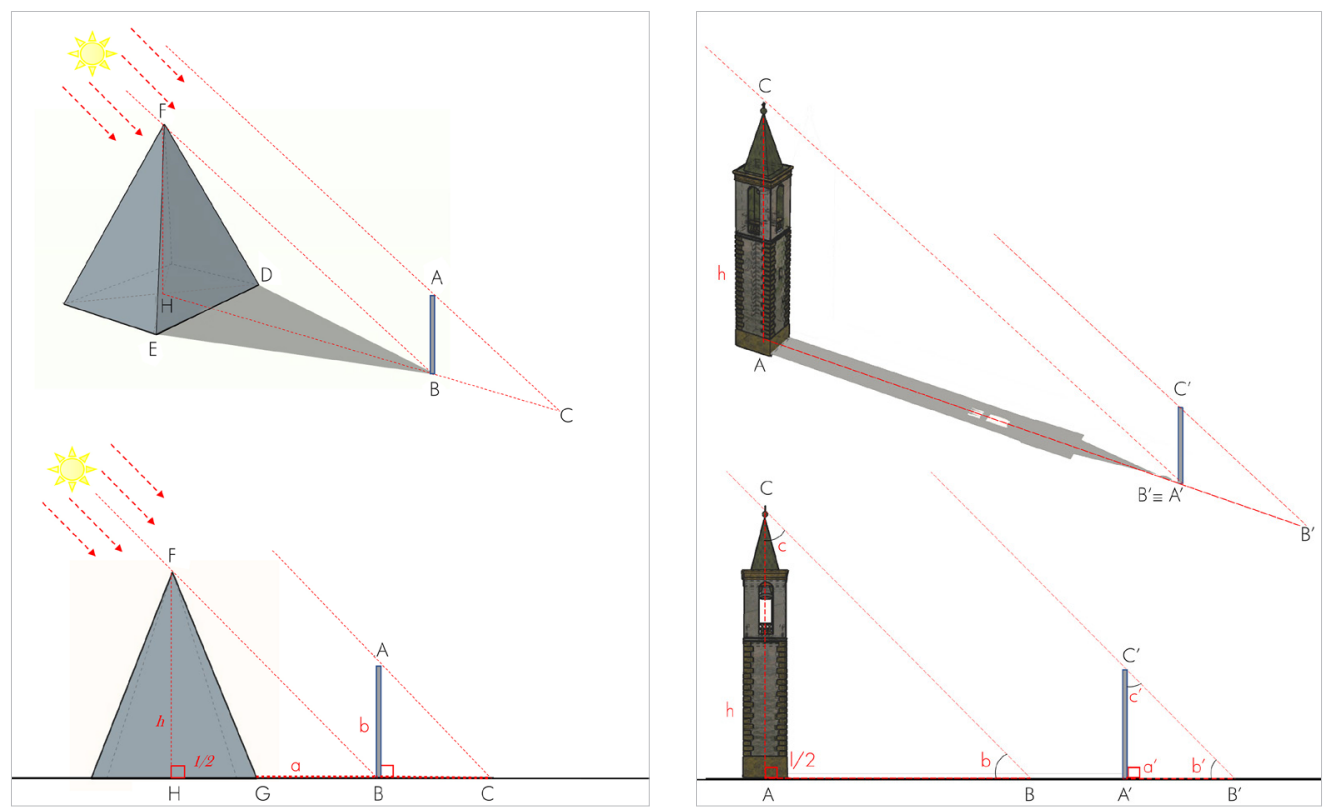
Fig. 3. Villard de Honnecourt, Taccuino Livre de portraiture. Measurement of the height of a tower by the method of similar triangles. Paris, BN, Fr 9093.

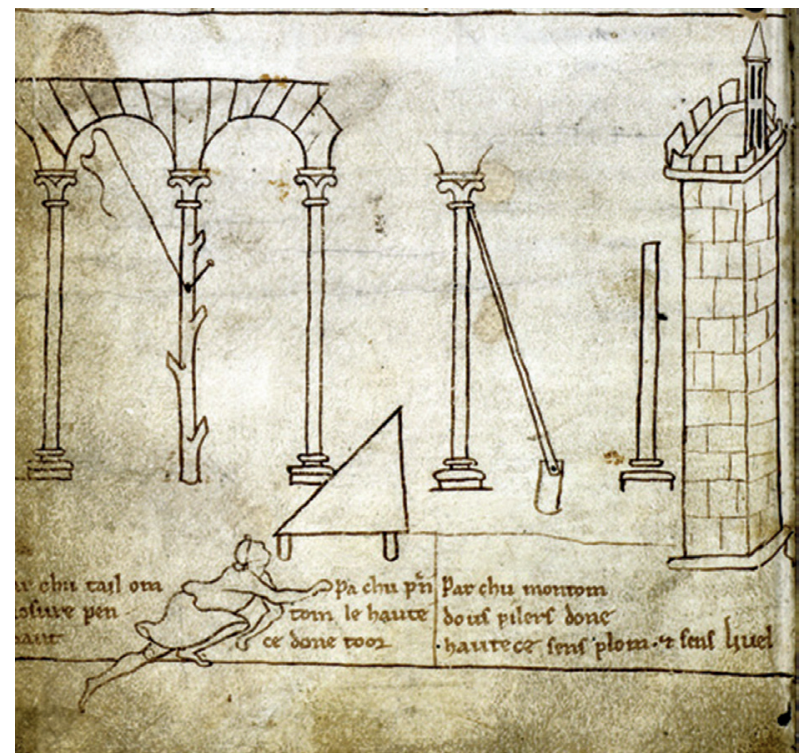

of heights. With regard to the publications examined, it should be noted that critical literature is particularly sparse. We do not mean the essays referred to, but wide-ranging studies which analyse the subject in depth and, above all, in comparison. It is divided into two main strands, the first using the usual traditional methods of detection, and in contrast, a prominent practice carried out by the new technological tools. The architectural relief of lean structures is closely related to the practice of surveying in which they converge several disciplines: geometric design, mathematics, surveying, military engineering. The passage from the theoretical analysis to the actual practice of the relief of these structures achieves a maximum development in the sixteenth century, with the design and use of a large number of instruments, the use of which has led to the reproduction of a measured space, therefore to achieve the ultimate objective of detection practice as defined by the Military Engineering Treaties [Zerlenga 1993] In this sense, traditional indirect detection techniques have been analysed, which base their use on the use of scientific knowledge in terms of trigonometry. The first comparison for the measurement of a height by indirect method is with the mathematician Thales of Miletus (640 a.C./625 a.C. ca. - 548 a.C./545 a.C. ca.), which measured the height of the Egyptian pyramids using geometric principles that exploit the measurement of shadows generated by them (figs. I, 2) [Klimpert 190 I] Starting from the eleventh century, the altimetric measurement of the towers uses techniques that are deduced from the application of the rigorous theo-

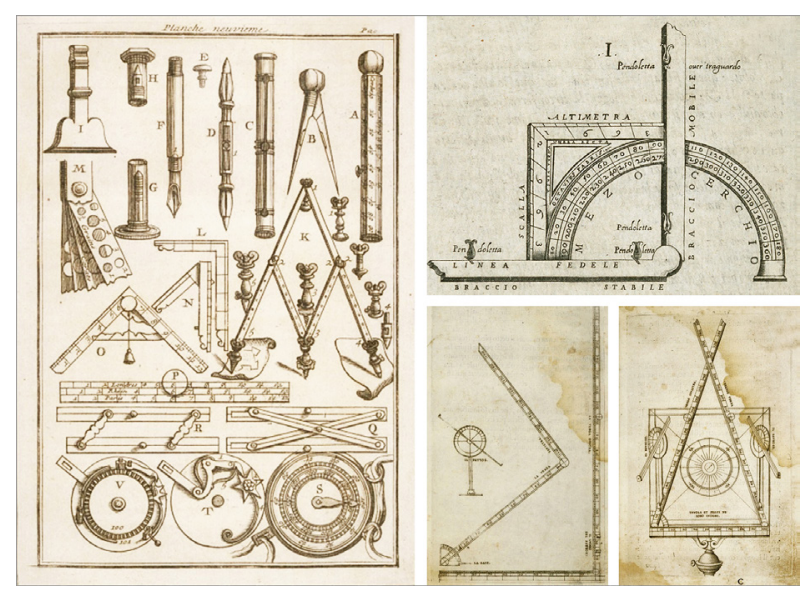

Fig. 4. Instruments of measurement used in antiquity: on the left a table of synthesis extracted from the treatise of $\mathrm{G}$. instruments used for the relief with direct method, on the right a matra on the right a squadra mobile extracted from the treatise of O. F extracted from the treatise of A. Foullon. 
retical and scientific advances in geometric disciplines: the Euclid Elements, the Almagesto of Tolomeo or the works on trigonometry by Teodosio and Fibonacci. The first specific techniques to be adopted to determine the height of a tower are described in the notebook Livre de portraiture (I 230-36 ca.) [Lassusa, Darcel I 858] by Villard De Honnecourt which indicates the geometric use of the system of similar triangles (fig. 3). Singular is the treatise by Geraldo di Aurillac then Pope Sylvester II (940-950 circa- I003) [Hock 20 I0], in which is illustrated for the first time a scientific methodology that bases its roots in the geometric assumptions of Arabic derivation, building the procedure on the geometric shape of the right triangle, whose practice will act as a practical and theoretical hinge from sec. XV. Another illustrious figure is Leonardo Pisano known by many as Fibonacci ( I 170 ca. - 1242 ca.) where in his work Pratica geometriae (1223) examines the measurement of heights with the use of a simple pole anticipating the assumptions illustrated later by Alberti. It will therefore be from the fifteenth century. that with the intensification of the relationship between science and technology we will see the publication of the treatises by artists, architects, military engineers [Docci, Maestri 1984], by means of which there is a strong relationship between the topographical measurement of the territory and that of architecture, thus spreading more concrete practices that exploit the use of scientific instrumentation appropriate to geometric detection. In ancient times surveyors, topographers and cartographers used tracing logics based on the collection-data of trigonometric points which often corresponded to architectural elements characterized by a significant height and, therefore, coincident with visual emergencies by virtue of which it was possible to obtain data for measuring distances as well as heights in space. The examination of the scientific treatise shows that these architectures not only served as visual 'markers', but also architectures' adequate to experiment new measurement techniques. In the text Sul modo di misurare il circuito o ambito di una Terra (1450-52) by Leon Battista Alberti (1404-1472) is illustrated the use of the dart to measure the height of a tower with the application of the theory of similar triangles, the similarity of the right triangles and Thales' theorem. Between the end of the sec. XV and the beginning of the sec. XVI in Italy were many treatists who used these architectures to illustrate the methods of use of the different measuring devices that would be merged in their topographical surveying practices-military: squadra mobile, il quadrante geometrico, il radio latino, l'olometro, as well as common dardi, lead wire or metric rods (fig. 4). Citing only some of the most significant treatises, in the treatise Del modo di misura le distanze [...] of I 564 by Cosimo Bartoli (I503-1572) he develops a singular synthesis of all the techniques hitherto used by his predecessors, through multiple cases that recall the Euclidean postulates (figs. 5, 6, 7); in the treatise Descrittione et uso dell'Holometro [...] del 1564 di Abel Fullone (15131563) The measurement of a tower is illustrated with the help of this instrument using the principle of similarity between triangles; in the treatise Radio Latino Istrumento giustissimo

Fig. 5. Bartoli C., Del modo di misurare le distantie [...], I 564. Measurement of a flat distance with the geometric dial (graphic elaboration by $\mathrm{M}$. Cicala).

Fig. 6. Bartoli C., Del modo di misurare le distantie [...], I 564. Measuring a flat line starting from the height of a tower (graphic elaboration by M. Cicala).
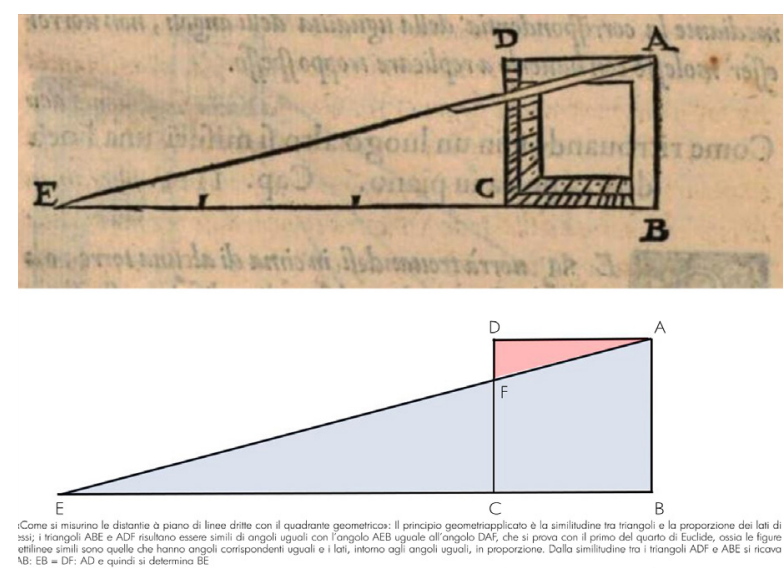

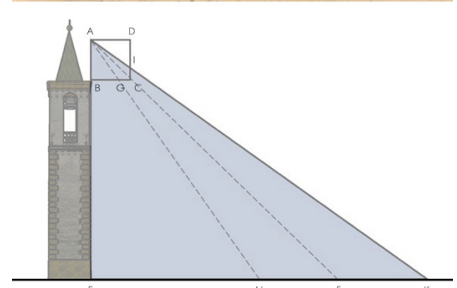


\& [...] del I 583, Egnazio Danti (I536- I586) show the rules of "as one measures the height of a tower from a valley" (fig. 8) [Danti I583] with the use of Latin radio; in the I598 Ottavio Fabri ( I545- I6 I I ca.) defines the use of the lame team to detect bell towers (fig. 9) [Fabri 1598]. This brief overview shows that starting from the second half of the century $\mathrm{XVI}$ measurement techniques and instruments will arrive at a high accuracy. At the same time, these technical and scientific findings demonstrate the extent to which these practices derive from the criteria of detection and indirect contemporary architectural design, performed with innovative technological tools that in fact shorten the distances between the past and the present.

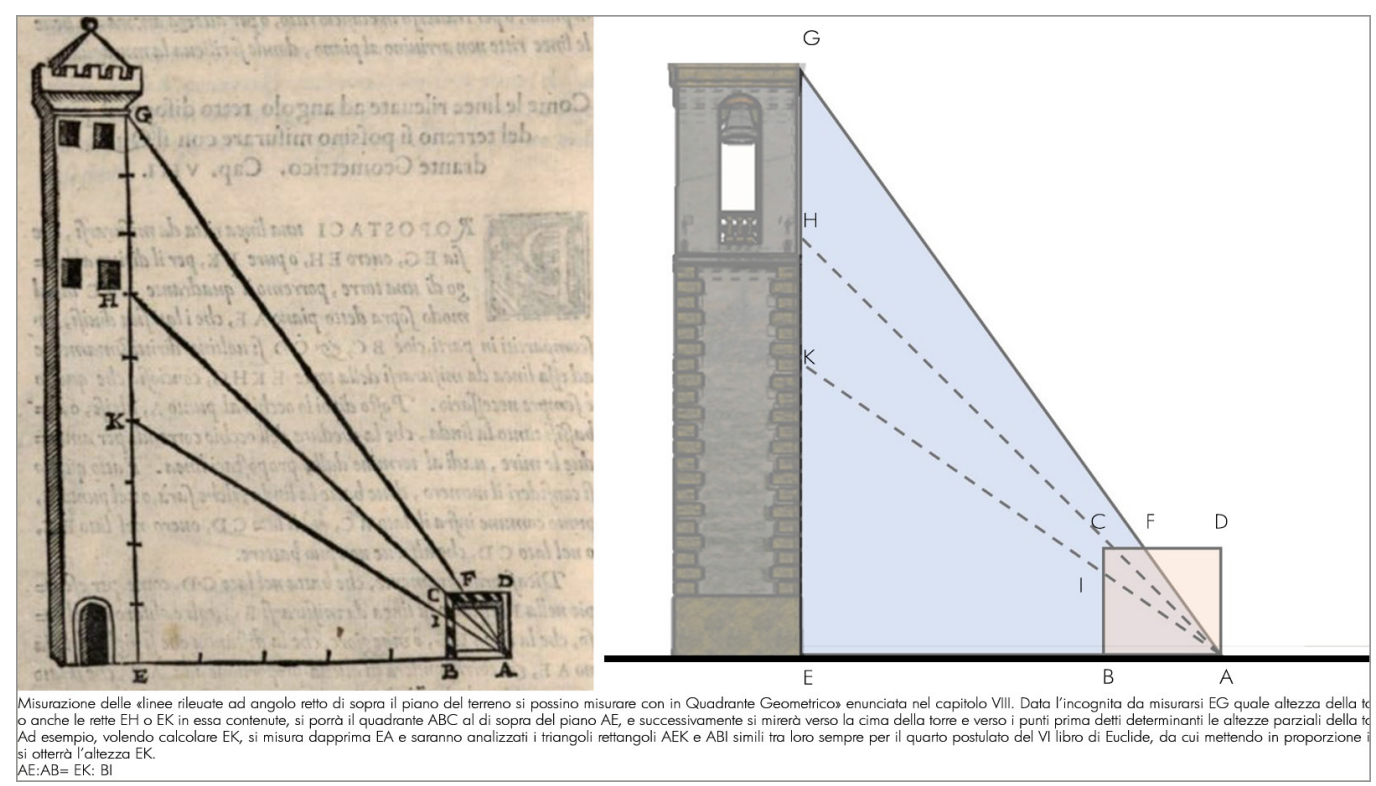

\section{The new technologies for the survey}

Nowadays, to detect a bell tower, it is possible to proceed by means of a survey using the direct method with a longimetric survey supported by the aid of simple measuring instruments, such as the meter, metric rods, the lead wire to verify the vertical direction and then identify the altimetric measurements; the use of the usual techniques of detection: the ascixis and ordinates, partial and progressive measurements or trilateration. But in the circumstance in which it is impossible to carry out a direct survey of the artifact, as demonstrated by almost all the cases examined, In support of the direct method it is inevitable the need to integrate the data obtained through the aid of indirect instrumentation 'modern' total stations, tacheometers, levels, spacers, laser scanner, APR, especially to detect inaccessible points. Specifically, with regard to the methodology of indirect modern survey greatly used for the survey of vertical architectures is that topographic, by means of which it is possible to define the object through the measurement of angles, while distance measurement is kept to a minimum, allowing remote reading of angle and length measurements using trigonometry principles. Among the various application examples of this first methodology the most significant found are the geometric relief of the Torrazzo di Cremona (CR) [Cuzzoni 202I], the bell tower of Pietrasanta (LU) [Russo 20I4] or even the bell tower of Gaeta (LT) [Pedone, Paribeni 20I4]examples that demonstrate how such a methodology as traditional classicist, which draws its origins in Greek and Roman architecture, if carried out in accordance, results can be obtained that are able to adequately reflect the objective reality of the well analysed, with a level of uncertainty as low as possible [Zerlenga 2000]. With the passing of time the techniques for the execu- 
Fig. 8. Danti E., Trattato de Radio Latino. Instrumento [..., 1583. Measurement the height of a bastion through the use of Latin elaboration by $M$. Cicala).

Fig. 9. Fabri O., L'uso della Squadra Mobile [...] I I 589 Definition of four cases for the determination of heights (graphic elaboration by $\mathrm{M}$. Cicala)
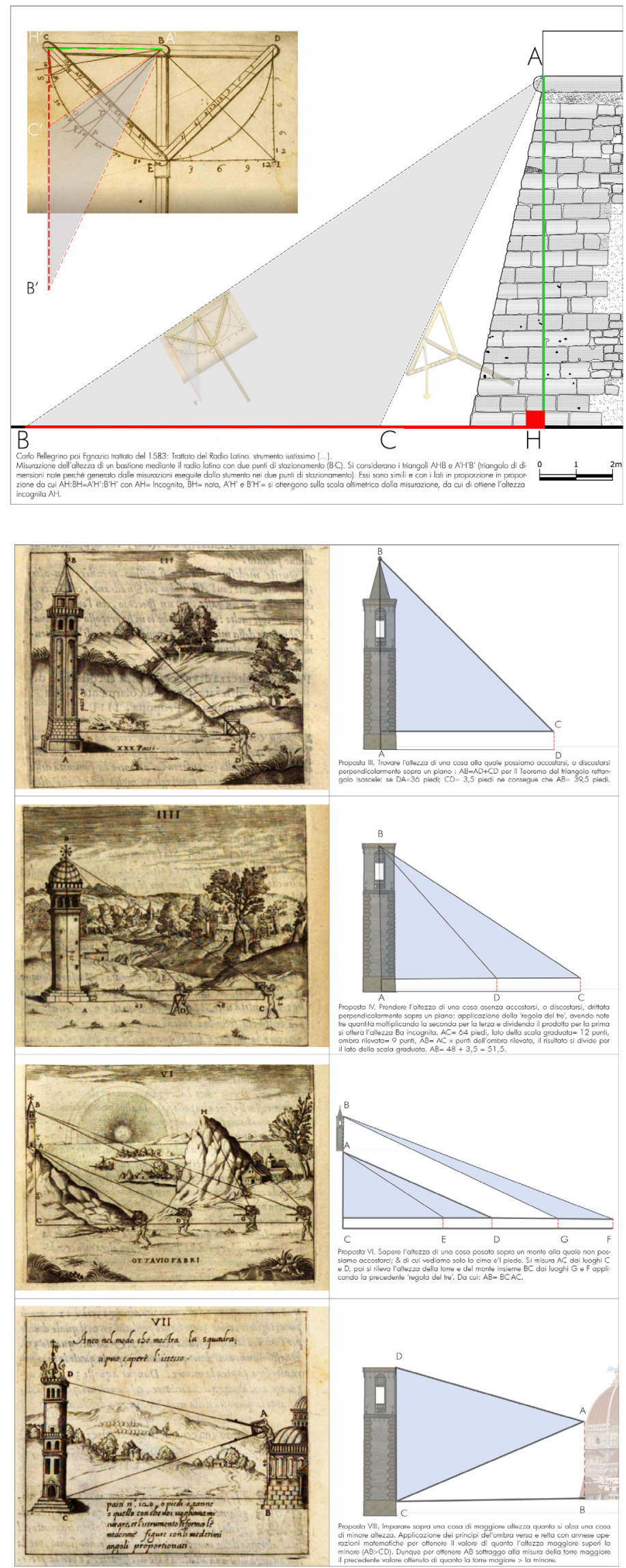
tion of the relief and its representation have become more and more refined, through the production of digital machinery and tools, capable of ensuring greater metric accuracy leading to a reduction in error deviation and time taken for data collection. Among these we have the methodology of digital photogrammetry that offers a simple and economical approach in order to metrically detect the cultural heritage. Used for the analysis of the ruins of the bell tower of the Confraternita of Misericordia in Savigliano [Lingua, Piumatti 2012], or again for the Duomo and the Bell Tower of Cremona [Balletti, Pilot 1998], this procedure, is made up of innovative software capable of handling all photogrammetric practices. The above documents describe a metric detection organization derived from frames and the post-construction of 3D models, so as to extract the traditional representations necessary to understand the object and plan a proper analysis procedure. Two other popular techniques for the survey procedure are the use of 3D scanners and drones or APR. The first method allows to obtain a 3D geometric acquisition of both the interior and the exterior where accessible, through a digitization campaign that allows to obtain a defined number of scans, which joined together generate clouds of points, from which it is possible to reconstruct the three-dimensional model. The use of APR is analyzed in detail here by illustrating the case study. The survey in question carried out on October 10,2016 used the use of DJI FC330 drone for the acquisition of geometric data of artifacts that were not reachable directly, such as roofs in their plano-altimetric development and especially for the clock tower (fig. 10). The technique used allowed the shots to generate a cloud of dense points through the software Photoscanpro (figs. $I I, 12$ ), so where each point is associated with position information $-x, y, z-$ and color $-R G B$ - therefore, creating a shape of the real of the artifact from a sequence of images,

Fig. 10. Model of the point cloud extracted with the program PhotoscanPro of the urban area of Riardo (CE).

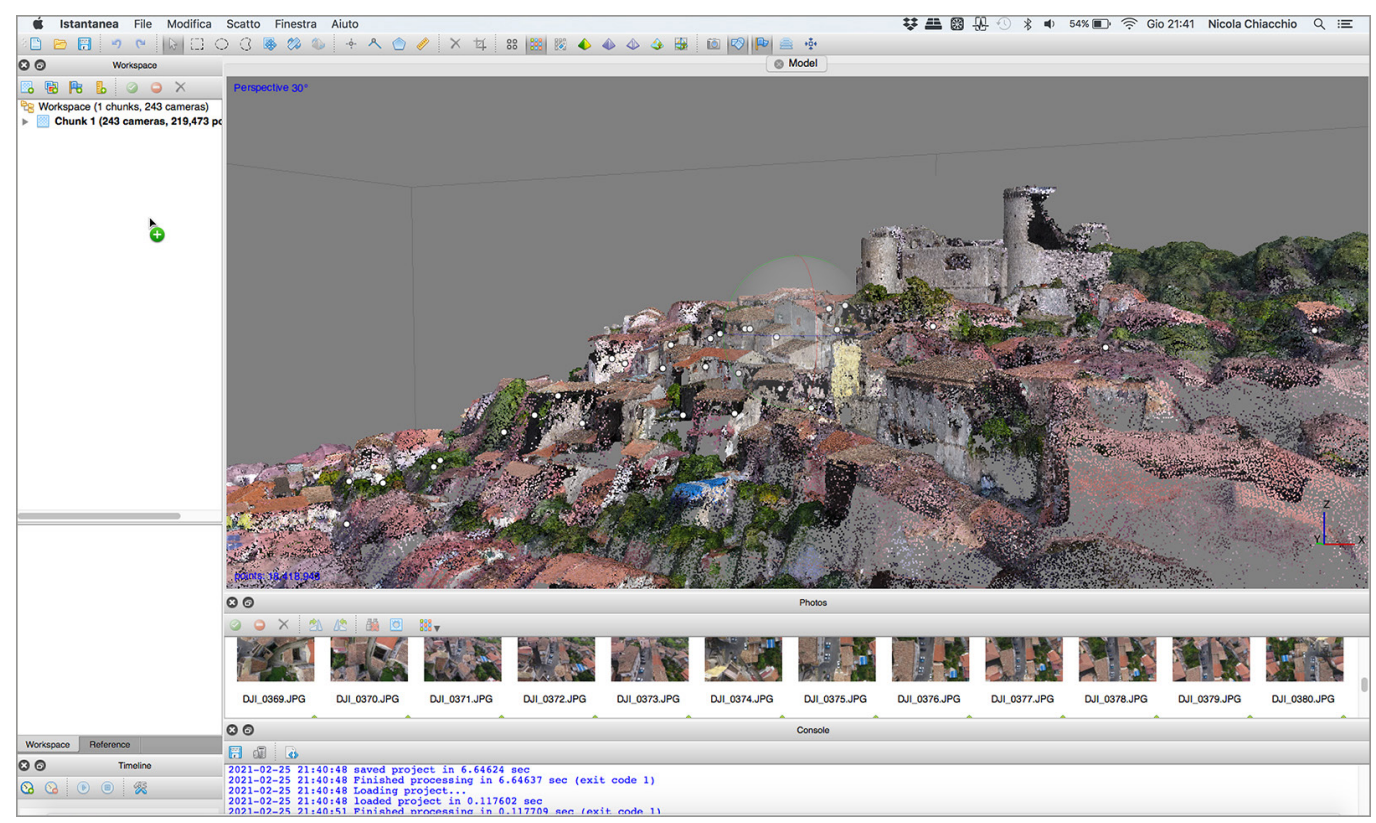

obtaining three-dimensional coordinates from two-dimensional coordinates. This practice, supported by the use of APR, allows to carry out urban surveys as well as individual artifacts in short time and to produce a model containing a considerable number of geometric and dimensional information, on the chromatic characteristics, material and the state of ruin of architectural elements. The aim here is not to deepen the explanation of the data acquisition process, but rather to underline how it acts as an innovative digital technique which results in new three-dimensional representation able to overcome the limitations of direct relief approaches, reaching complete models from which to extrapo- 
Fig. II.Three-dimensiona model derived from the fusion of geo-referenced points generated by the drone relief.

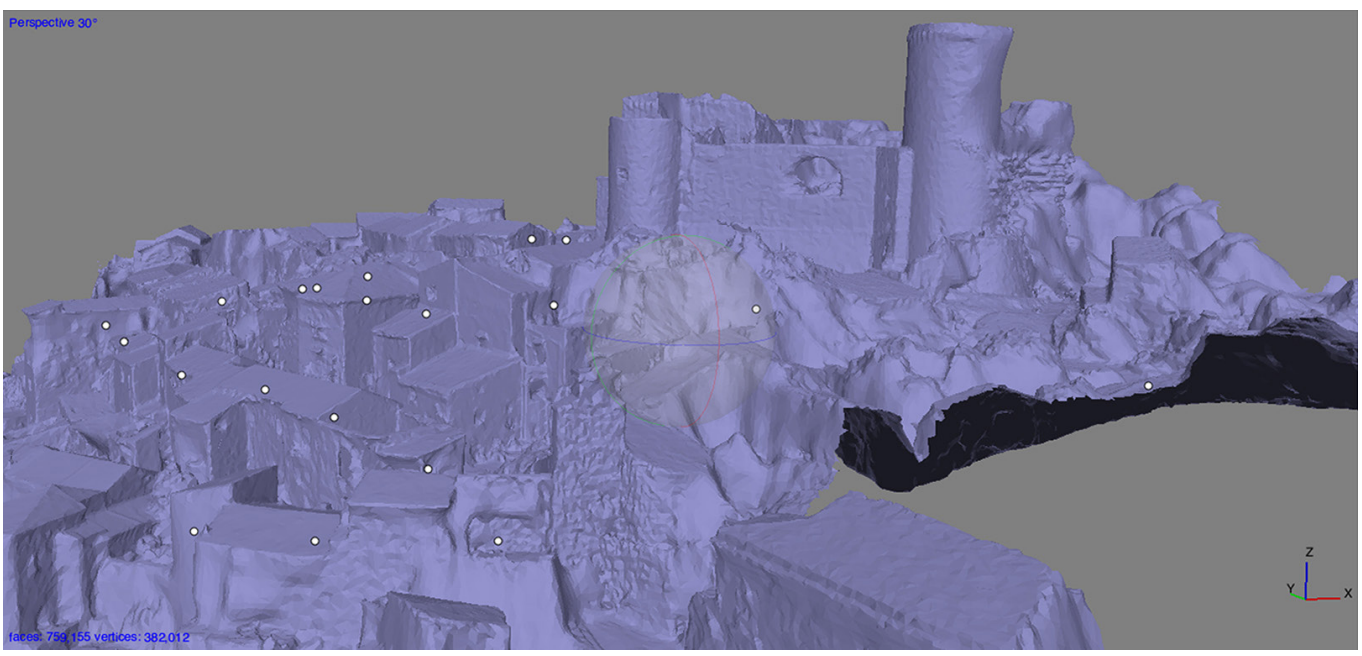

late a considerable amount of information. But by highlighting that such a process is 'modern' supported by the technology developed in the last twenty years and in continuous evolution descends from the principles of descriptive geometry and methods of indirect relief adopted in antiquity.

\section{Conclusions}

The paper's aim is to underline the inseparable link that exists between the languages used in the past and the contemporary and modern ones for the architectural survey: on the one hand the methods of ancient detection that despite being subject to a greater degree of uncertainty -because of the instrumentation not as well calibrated as that available today- they adopt the practices of Euclidean geometry as the cornerstone of a suitable well-established scientific method, able to reduce distances over time and that is projected within the new digital expressive forms of new technologies. The new technologies used for the relief, that appear more and more technologically perfect show in itself the progress regarding the techniques of the past but whose use must however be carefully filtered, avoiding the risk of producing an elaboration and representation of data incapable of communicating the singular characteristics of the architecture examined and respecting the communicative principles of design and its representation with a universal expressive capacity.

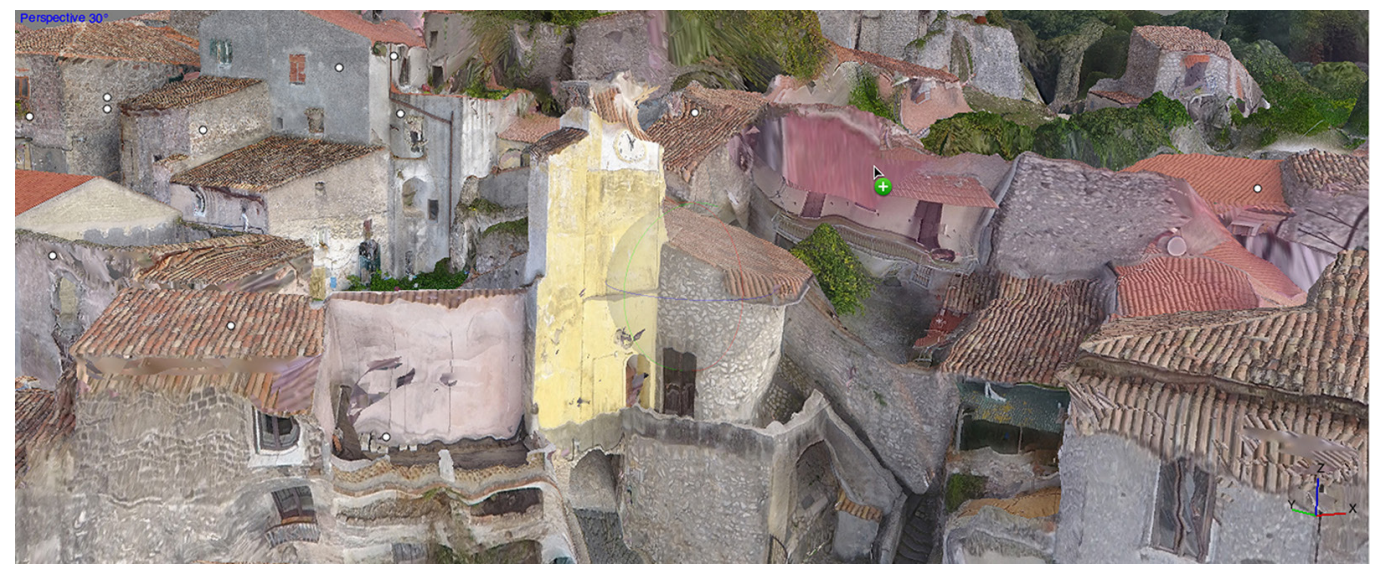




\section{Notes}

[I] Among these lean architectures, specifically the masonry bell towers of Naples have been analyzed and continuous studies are in progress, in the field of research conducted in teams, within the competitive project intra/ University PREVENT - Integrated PRocedure for assEssing and improVing the resiliENce of existing masonry bell Towers at territorial scale by Programma Valere 2019 from the Università degli Studi della Campania "Luigi Vanvitelli" and coordinated by Gianfranco De Matteis (principal investigator) with Sergio Sibilio and Ornella Zerlenga (team leaders).

\section{Acknowledgements}

We would like to thank the architect Nicola Chiacchio for the collaboration with the execution of the relief with drone and the associated processing of computerized data.

\section{References}

Aita D. et al. (2017). 3-Dimensional geometric survey and structural modelling of the dome of pisa cathedral. The International Archives of the Photogrammetry, Remote Sensing and Spatial Information Sciences, pp. 39-46.

Alberti L. B., Bartoli C. ( 1568$)$. Opuscoli morali di Leon Battista Alberti gentil'huomo firentino: né quali si contengono molti ammaestramenti, necessarij al viuer de' l'huomo, così posto in dignità, come priuato. Tradotti, \& parte corretti da Cosimo Bartoli. Venezia: Franceschini editore, pp. 507-512.

Balletti C., Pilot L., Brumana R. (1998). Plan, execution and rapresentation of an architectonic survey: the torrazzo of Cremona, Italy. International Archives of Photogrammetry and Remote Sensing, vol. XXXII, Part. 5. Hakodate, pp. 2I 0-20I 5.

Bartoli C. (I564). Del modo di misurare le distantie, le superficie, i corpi, le piante, le prouincie, le prospettiue, \& tutte le altre cose terrene, che possono occorrere a gli huomini, secondo le vere regole d'Euclide, \& de gli altri piu lodati scrittori. Venetia: per Francesco Franceschi Sanese.

Cirillo V., Cicala M. (202I). Redrawing the future of Naples' bell towers. the 'prevent' project. In Apega - XV International conference on graphic expression applied to building, Redrawing the Future. Tenerife, La Laguna, on May 27-29 202I (in corso di pubblicazione).

Cirillo V., Cicala M. (2020).Valorizzare l'architettura religiosa attraverso l'arte di strada. II campanile della chiesa di Maria Santissima del Carmine alle Fontanelle nel progetto PREVENT. In A. di Luggo, O. Zerlenga (a cura di). Street Art. Drawing on the Walls. Napoli: La scuola di Pitagora. pp. 95-121.

Cuzzoni M. Esempio di Studio del Restauro di un Campanile <https://www.campanologia.it/contenuto/pagine/0 I-ATS/ATS-P0 I/ ATS-POI-05-Progetto-Cantiere-Campanile.htm> (accessed 2020, January 25).

Danti E. ( I 583). Trattato del Radio Latino. Istrumento giustissimo \& facile più d'ogn'altro per prendere qual si voglia misura, \& positione di luogo tanto in Cielo, come in Terra. Il quale oltre alle operationi proprie sue fa anco tutte quelle della gram Regola di C. Tolomeo, et dell'antico Radio Astronomico. Inventato dall'Ill.mo et Eccell.mo Latino Orsini. di: Latino Orsini, I 6. sec. Egnazio Danti; Moretti, Marcantonio \& Brianza, Giacomo. Roma: Appresso Marc'Antonio Moretti, \& lacomo Brianzi.

Docci M., Maestri D. (1993). Storia del rilevamento architettonico e urbano. Bari: Laterza Editore.

Docci M., Maestri D. (1984). Il rilevamento architettonico. Storia metodi e disegno. Roma-Bari: Laterza Editori.

Fabri O. ( I 598). L'uso della Squadra Mobile con la quale per teoria et per pratica si misura geometricamente ogni distanza, altezza, profondità. S'impara à perticare, livellare, et pigliare in disegno le Città, Paesi et Provincie. II tutto con le sue dimostrationi intagliate in rame. Da Ottavio Fabri messa in luce. Venezia: appresso Francesco Barilleti, all'insegna del Mondo.

Foullon o Foulon, A. ( 1564). Descrittione, et vso dell'holometro. Per saper misurare tutte le cose, che si possono veder coll'occhio cosi in lunghezza, \& larghezza; come in altezza, \& profondità, ritrovato per Abel Fullone, valletto di camera del re di Francia, necessario a quelli che vogliono prontamente et senza fare alcuna ragione arithmetica sapere le distantie dè luoghi, misurare la terra, \& tor in disegno paesi, \& città. Venezia: appresso Giordano Ziletti, al segno della Stella.

Hock K. F., Stelzi G. (20 I0). Gerberto, o Sia Silvestro II Papa ed il Suo Secolo (I 846). Whitefish: Editore Kessinger Publishing, LLC.

Klimpert R. (190I). Storia della geometria, tradotto, con note e aggiunte dal Professore di Topografia nel R. Istituto Tecnico di Bari, Pasquale Fantasia. Bari: Gius. Laterza e Figli.

Lassus J. B. A., Darcel A. (1858). Album de Villard de Honnecourt, Architecte du XIlle siècle: manuscrit publié en fac-similé, annoté, précédé de considérations sur la renaissance de l'art français au XIXe siècle et suivi d'un glossaire. Parigi: Impr. Imperiale.

Lingua A., Piumatti P., Rinaudo F. (2012). Digital photogrammetry:a standard approach to cultural heritage survey. In The International Archives of the Photogrammetry, Remote Sensing and Spatial Information Sciences, vol. XXXIV, Part. 5/W I 2, pp. 2 I 0-2 I 5.

Lupicini A. ( 1582). Discorso sopra la fabrica, e uso delle nuove verghe astronomiche. Firenze: appresso Giorgio Marescotti.

Meschini A., Rossi D., Sicuranza F. (20I4). An integrated survey experience: San Francesco complex in Monterubbiano. In P. Giandebiaggi, C.Vernizzi (a cura di). Italian survey \& international experience. Atti del XXXVI Convegno Internazionale dei docenti della Rappresentazione, UID. Parma, I 8-20 settembre 20 I4, pp. 943-952. Roma: Gangemi Editore.

Orsini L. (16|5). Trattato del radio latino [...] il quale oltre alle operazioni proprie sue fa anco tutte quelle della Gran Regola di Tolomeo et dell'antico radio astronomico, con i commentatori di Egnazio Danti. Roma: appresso Marc'Antonio Moretti e Giacomo Brianzi.

Pedone S., Paribeni A. (2018). Di Bisanzio dirai ciò che è passato, ciò che passa e che sarà. Scritti in onore di Alessandra Guiglia. Roma: Bardi Editore.

Pomodoro G. (I 603). Geometria Prattica dichiarata da Giovanni Scala, sopra le tavole dell'Ecc. mo Mathematico Giovanni Pomodoro tratte d'Euclide e altri autori. Roma: Appresso Giovanni Martinelli. 
Russo V. (20|4). Paesaggio come architettura. Identità e conservazione del sito culturale di Crapolla. Nardini Editore.

Russo M., Manferdini A. (20 I 4). Integration of different methodologies for the high resolution survey for complex architectures. The Pomposa Abbey case study. In P. Giandebiaggi, C.Vernizzi (a cura di). Italian survey \& international experience. Atti del XXXV Convegno Internazionale dei docenti della Rappresentazione, UID. Parma, I8-20 settembre 20 I4, pp. 989-998. Roma: Gangemi Editore.

Valenti G. M., Baglioni L. (20|4). Experimential Applications of Architectural details survey using micro-drones. In P. Giandebiaggi, C.Vernizzi (a cura di). Italian survey \& international experience. Atti del XXXVI Convegno Internazionale dei docenti della Rappresentazione, UID. Parma, I8-20 settembre 20 I4, pp. I025-1030.

Vitruvio M. P. (1990). De Architettura.Volume I, Libro X.Traduzione Luciano Migotto. Pordenone: Edizione Studio Tesi.

Zerlenga O. (1993). II disegno dell'architettura fortificata nel XVI secolo. Realtà costituite e fonti iconografiche a confronto. Tesi di dottorato. Università degli Studi di Palermo.

Zerlenga O. (2000). Sulle ali di una farfalla. Esperienze di rilievo urbano e ambietale. Napoli: CUEN.

Zerlenga O. (2009a).... Misure in divenire... Measures in to become... Rilievo multidimensionale dei nuovi contesti urbani fra permanenze e contaminazioni. Napoli: La Scuola di Pitagora editrice.

Zerlenga O. (2009b). Formazione e innovazione all'Università. Indirizzo Arte e Disegno_Indirizzo Tecnologico. Foggia: Claudio Grenzi Editore.

Zerlenga O., laderosa R. (202I). PREVENT: Survey by UAV of the bell towers. In Apega - XV International conference on graphic expression applied to building- Apega 2021, Redrawing the Future. Tenerife, La Laguna, on May 27-29, 2021 (in corso di pubblicazione).

Zerlenga O. et al. (202I). Napoli rappresentata dai suoi campanili. Un caso studio: il progetto PREVENT. In A. Palomba, M. I. Pascariello (a cura di). La Citta' Palinsesto. Tracce sguardi e narrazioni sulla complessità dei complessi urbani storici. CIRICE 2020. IX Convegno internazionale. Napoli, $10-12$ giugno 2021 (in corso di pubblicazione).

Zevi B. (1948). Saper vedere l'Architettura.Torino: Einaudi Editore.

\section{Author}

Margherita Cicala, Università della Campania “Luigi Vanvitelli”, margherita.cicala@unicampania.it

To cite this chapter: Cicala Margherita (202I). Approcci metodologici finalizzati alla conoscenza geometrica di torri e campanili/Methodological approaches aimed at the geometric knowledge of towers and bell towers. In Arena A. Arena M.. Mediati D. Raffa P. (a cura di). Connettere. Un disegno per annodare e tessere. Linguaggi Distanze Tecnologie. Atti del $42^{\circ}$ Convegno Internazionale dei Docenti delle Discipline della Rappresentazione/ Connecting. Drawing for weaving relationship. Languages Distances Technologies. Proceedings of the $42^{\text {th }}$ International Conference of Representation Disciplines Teachers. Milano: FrancoAngeli, pp. 490-509. 